\title{
Teacher candidates' state of using digital educational games
}

\author{
Ayşe Alkan', Hüseyin Mertol ${ }^{2}$ \\ ${ }^{1}$ Samsun Directorate of National Education, Turkey \\ ${ }^{2}$ Department of Turkish and Social Studies Education, Süleyman Demirel University, Turkey
}

\begin{tabular}{l}
\hline Article Info \\
\hline Article history: \\
Received Mar 25, 2019 \\
Revised Apr 17, 2019 \\
Accepted May 18, 2019 \\
\hline
\end{tabular}

Keywords:

Educational game

Digital game

Information technologies

Teacher

\begin{abstract}
The rapidly developing information technologies of our age offer new opportunities in every aspect of our lives. The use of information technologies in educational environments is an important element in creating enriched learning environments. Educational digital games used in teachinglearning environments help students to develop motivation, problem-solving, strategy development skills and creativity. The purpose of this research was to determine the teacher candidates' state of using digital educational games. The study group of the research consisted of $4^{\text {th }}$ grade teacher candidates who are studying in the social sciences and classroom teaching departments of Süleyman Demirel University during the 2018/2019 academic year. It has been found that men teacher candidates were more positive than women teacher candidates. Teacher candidates studying social sciences were more positive than those studying classroom teaching. Although teacher candidates were concerned about using educational digital games, they were eager to use these games.
\end{abstract}

Copyright $(\mathcal{C} 2019$ Institute of Advanced Engineering and Science. All rights reserved.

\section{Corresponding Author:}

Ayşe Alkan,

Samsun Directorate of National Education,

Kale Mahallesi, Atatürk Blv. Yeni Hükümet Konağı, 55030 İlkadım/Samsun, Turkey

Email: ayse.alkan55@gmail.com

\section{INTRODUCTION}

The use of rapidly developing and advancing information technologies in education gives the opportunity to create new learning environments. The importance of using Information Technologies in educational environments can be explained by the cone of life. The "cone of life" developed by American educator Edgar Dale was developed to help educators for the selection of learning experiences to achieve target-behavior, using the relationships between experiences and the formation of concepts. According to this model, higher is the number of sensory organs involved in the learning process, the better we learn and the later we forget, we learn the best by doing ourselves, we learn the most of what we have learned with our eyes, the best teaching method is from concrete to abstract and from simple to complex [1].

One of the most used Information Technologies tools is computers. Computer-assisted education (CAE) is one of the areas in which computers are used in education. In computer-assisted education, computers are used as a tool to help teachers to enrich the educational activities and to improve the quality of education [2]. Kamaci and Durukan also emphasize [3] that computer-assisted education increases the success by $10-18 \%$ compared to traditional teaching. The software types used in computer-assisted education are special course softwares, exercise softwares, games and simulation softwares.

While special course softwares are used to teach new information, Exercise softwares are softwares that enable students to practice using the information they have learned beforehand. Simulations: While providing situations that control the limiting factors, such as danger, cost, time and space, which are similar to real situations, Games can be considered to be effective in developing learning, problem solving, and strategy development skills because the player has to use problem solving skills to overcome obstacles. 
Prensky states that [4] in the 21st century, what will shape education, is to make it funny and interesting by eliminating elements that make learning difficult. Games developed with the help of information technologies are widely used by individuals of all age groups. Garris, Ahlers and Driskell describe computer games [5] as a fun, rules-bound, entertainment environment that is voluntarily played by people.

Although the games are generally used for entertainment purposes, they can also be used in educational activities. Educational computer games help students to develop their creativity, decision-making ability, imagination, and fast thinking skills. While the games, which support the physical, cognitive, affective and social development of children, ensure at the same time the children have fun, reinforce the knowledge they have learned, reah the target behaviors given in the educational programs, make them think fast and take decisions, they also provide a natural environment in which they also perform creation activites $[6,7]$. Çankaya and Karamete also stated that [8] educational computer games can be used as alternative, complementary and enrichment to other teaching methods for teaching or educational purposes.

Educational computer games can be used on desktop computers, laptops, tablet computers, smartphones. Attention should be paid to the use of games for educational purposes as well as the selection of educational computer games that are appropriate to the characteristics of the target audience and the behaviors to be gained. Doğrusoy and İnalı stated that [9] there may be many points to be considered during the design phase in order to provide the balance between education and entertainment elements and to obtain the necessary educational content from the game environment for the student.

Prensky gathered the characteristics that a game should have in order to be educational in six groups [10] these are:

a. Rules: The rules determine the boundaries of games and provide a variety of ways for users to reach their goal.

b. Goal and objectives: Creates a sense of duty in the player and ensures him to voluntarily play the game and spend time and make effort.

c. Feedbacks: Informs about how the user progresses against the target using the feedbacks.

d. Fight/race/challenge/contrast: Fight, race, challenge and contrast are the problems that are tried to be solved in the game. In the game, the user can feel fear and excitement like in real life without having to face real dangers. This motivates the user and allows him to continue and complete the game.

e. Interaction: The interaction is considered in two aspects. First, it is the interaction of the players or the computer; it can be called a feedback. The second is the social situation that players create with each other while playing the game.

f. Presentation or story: it is what the game is about. The story of the game can be given at the beginning of the game or indirectly within the game.

According to the characteristics of the target audience, the importance of the teacher in preparing an enriched and differentiated environment suitable for the behaviors to be gained is an undeniable fact. Teacher candidates are required to use information technologies in organizing education-learning environments and to choose the appropriate equipment during their education. In this study, the aim was to determine the opinions of the teacher candidates on using educational digital games by studying their state of using these games.

\section{RESEARCH METHOD}

In this study, relational research model of quantitative methods was used to status of teacher candidates' use of educational digital games. The quantitative method is a type of research, which can be observed objectively by observing facts and events in a quantifiable and quantifiable way [11]. The relational survey model is a research model that aims to determine the presence and /or degree of coexistence between two or more variables [12].

This research was conducted in 2018-2019 academic year. A total of 100 teacher candidates (65 females and 35 males) studying in various departments of Süleyman Demirel University Faculty of Education constitute the study group of this study.

In this study, it was aimed to evaluate the use of educational digital games by teacher candidates. In this context, to serve the purpose; It was used as a data collection tool from the scale adapted to Turkish by Sarıgöz, Bolat, Alkan developed [13] by Bonanno and Kommers. The scale consists of 21 items. Using a 5point Likert-type rating; ( $4=$ Totally Agree, 3 = Agree, $2=$ Undecided, $1=$ Disagree, $0=$ Never Agree).

Data analysis was performed by SPSS program. In addition to descriptive statistics, T-test was applied and significance was evaluated at $\mathrm{p}<0.05$. In the statistical studies, the tables of the scale items that have a significant difference according to the gender and the reading section are given. 


\section{RESULTS AND DISCUSSION}

In this section, the results of the analysis of the responses to the applied scale are given. Table 1 presents the frequency (f) and percentage (\%) distributions of the gender of the students of the study. According to Table 1, a total of 100 teacher candidates, 65 of which were women and 35 were men, participated in the study.

Table 1. Gender

\begin{tabular}{ccc}
\hline Gende & $\mathrm{f}$ & $\%$ \\
\hline Women & 65 & 65 \\
Men & 35 & 35 \\
Total & 100 & 100 \\
\hline
\end{tabular}

Table 2 presents the frequency (f) and percentage (\%) distributions of the departments of the students. According to Table 2, 56 of the teacher candidates who participated in the research were studying in social sciences and 44 were in classroom teaching.

Table 2. Department

\begin{tabular}{ccc}
\hline Department & $\mathrm{f}$ & $\%$ \\
\hline Social sciences & 56 & 56 \\
Classroom teaching & 44 & 44 \\
Total & 100 & 100 \\
\hline
\end{tabular}

According to Table 3, it was found that the average for 21 items ranged from 2.51 to 99 . In this context, it is understood that the overall average of all items for the relevant scale is 1.89 , and the responses of students are generally focused on the undecided option.

The scale item with the highest average in 21 items: "I can learn a lot of information I need to know about a digital game", but the lowest mean is; It was found that "I hesitate to use an educational digital game with the concern that I might look stupid."

Table 3. Average and standard deviation values with scale items

\begin{tabular}{|c|c|c|}
\hline Scale Items & $\begin{array}{c}\bar{X} \\
1.89\end{array}$ & $\begin{array}{l}\mathrm{SD} \\
1.10\end{array}$ \\
\hline $\begin{array}{l}\text { When I'm given the opportunity to play a popular digital game, I'm afraid I'll have trouble navigating } \\
\text { through the game. }\end{array}$ & 1.47 & 1.21 \\
\hline I'm working better because educational digital games make me feel better. & 2.05 & 1.13 \\
\hline I can learn a lot of information I need to know about a digital game. & 2.51 & 1.05 \\
\hline I find it difficult to learn if a subject is taught in digital play. & 1.19 & 1.00 \\
\hline I hesitate to use an educational digital game with the concern that I might look stupid. & .99 & 1.05 \\
\hline Educational digital games enrich our learning experience to a degree that requires extra effort. & 2.50 & 1.05 \\
\hline I'm having trouble controlling the game when I'm playing games on the computer. & 1.26 & 1.15 \\
\hline I'm not worried when I use an educational digital game. & 2.33 & 1.21 \\
\hline I can do whatever I want to do on the computer playing an educational digital game. & 2.33 & 1.09 \\
\hline I only play educational digital games when told. & 1.78 & 1.15 \\
\hline When I use an educational digital game, I need an experienced person. & 1.52 & 1.14 \\
\hline Playing educational digital games doesn't scare me in any way. & 2.45 & 1.17 \\
\hline We'll be able to get many of the benefits we'll get from an educational digital game, or in other ways. & 2.41 & 1.12 \\
\hline I refrain from playing educational digital games. & 1.43 & 1.13 \\
\hline $\begin{array}{l}\text { When I encounter a problem using an educational digital game usually I can solve that problem in one } \\
\text { or more ways. }\end{array}$ & 2.22 & 1.09 \\
\hline I hesitate to use the computer to play games because I'm afraid to make mistakes that I can't fix. & 1.36 & 1.12 \\
\hline Educational digital games offer more interesting and creative ways to learn. & 2.47 & 1.17 \\
\hline I will regularly use educational digital games throughout the school. & 1.95 & 1.11 \\
\hline I need someone to tell me the best ways to use an educational digital game. & 1.81 & 1.10 \\
\hline Educational digital games distract me. & 1.12 & .945 \\
\hline Educational digital games provide opportunities for more efficient learning. & 2.61 & 1.11 \\
\hline
\end{tabular}

Int. J. Eval. \& Res. Educ. Vol. 8, No. 2, June 2019: 344 - 350 
Table 4 shows a meaningful difference according to gender [ $\mathrm{t}(97)=2.43, \mathrm{p}<.05]$. The attitudes of men candidate teachers $(\bar{X}=2.85)$ are more positive than women candidate teachers $(\bar{X}=2.32)$.

Table 4. "Educational digital games enrich our learning experience to a degree that requires extra effort"

\begin{tabular}{ccccccc}
\multicolumn{7}{c}{ item's t-test results according to gender } \\
\hline Gender & $\mathrm{N}$ & $\bar{X}$ & $\mathrm{~S}$ & $\mathrm{sd}$ & $\mathrm{t}$ & $\mathrm{p}$ \\
\hline Women & 65 & 2.32 & 1.09 & 97 & 2.43 & .01 \\
Men & 35 & 2.85 & .89 & & & \\
\hline
\end{tabular}

Table 5 shows a significant difference according to gender $[\mathrm{t}(96)=2.28, \mathrm{p}<.05]$. The attitudes of men candidate teachers $(\bar{X}=2.82)$ are more positive than women candidate teachers $(\bar{X}=2.26)$.

Table 5. "Playing educational digital games doesn't scare me in any way" item's t-test results

\begin{tabular}{ccccccc}
\multicolumn{7}{c}{ according to gender } \\
\hline Gender & $\mathrm{N}$ & $\bar{X}$ & $\mathrm{~S}$ & $\mathrm{sd}$ & $\mathrm{t}$ & $\mathrm{p}$ \\
\hline Women & 65 & 2.26 & 1.17 & 96 & 2.28 & .02 \\
Men & 35 & 2.82 & 1.11 & & & \\
\hline
\end{tabular}

Table 6 shows a significant difference according to the department [t $(98)=2.07, \mathrm{p}<.05$ ]. Classroom teacher candidates' attitudes $(X=1.75)$ are higher than social sciences teacher candidates $(\mathrm{X}=1.25)$.

Table 6. "When I'm given the opportunity to play a popular digital game, i'm afraid i'll have trouble navigating through the game" item's t-test results according to department

\begin{tabular}{ccccccc}
\hline Department & $\mathrm{N}$ & $\bar{X}$ & $\mathrm{~S}$ & $\mathrm{sd}$ & $\mathrm{t}$ & $\mathrm{p}$ \\
\hline Social sciences & 56 & 1.25 & 1.20 & 98 & 2.07 & .04 \\
Classroom teaching & 44 & 1.75 & 1.18 & & & \\
\hline
\end{tabular}

Table 7 shows a significant difference according to the department [t $(97)=2.37, \mathrm{p}<.05]$. Classroom teacher candidates' attitudes $(\bar{X}=1.45)$ are higher than social sciences teacher candidates $(\bar{X}=.98)$.

Table 7. "I find it difficult to learn if a subject is taught in digital play" item's t-test results according to department

\begin{tabular}{ccccccc}
\hline Department & $\mathrm{N}$ & $\bar{X}$ & $\mathrm{~S}$ & $\mathrm{sd}$ & $\mathrm{t}$ & $\mathrm{p}$ \\
\hline Social sciences & 56 & .98 & .91 & 97 & 2.37 & .01 \\
Classroom teaching & 44 & 1.45 & 1.06 & & & \\
\hline
\end{tabular}

Table 8 shows a significant difference according to the department [t $(98)=2.63, \mathrm{p}<.05]$. Classroom teacher candidates' attitudes $(\bar{X}=1.29)$ are higher than social sciences teacher candidates $(\bar{X}=.75)$.

Table 8. "I hesitate to use an educational digital game with the concern that I might look stupid" item's t-test results according to department

\begin{tabular}{ccccccc}
\hline Department & $\mathrm{N}$ & $\bar{X}$ & $\mathrm{~S}$ & $\mathrm{sd}$ & $\mathrm{t}$ & $\mathrm{p}$ \\
\hline Social sciences & 56 & .75 & .97 & 98 & 2.63 & .01 \\
Classroom teaching & 44 & 1.29 & 1.09 & & & \\
\hline
\end{tabular}


Table 9 shows a significant difference according to the department [t $(97)=2.35, \mathrm{p}<.05]$. Classroom teacher candidates' attitudes $(\bar{X}=2.70)$ are higher than social sciences teacher candidates $(\bar{X}=2.18)$.

Table 9. "We'll be able to get many of the benefits we'll get from an educational digital game, or in other ways" item's t-test results according to department

\begin{tabular}{ccccccc}
\hline Department & $\mathrm{N}$ & $\bar{X}$ & $\mathrm{~S}$ & $\mathrm{sd}$ & $\mathrm{t}$ & $\mathrm{p}$ \\
\hline Social sciences & 56 & 2.18 & 1.15 & 97 & 2.35 & .02 \\
Classroom teaching & 44 & 2.70 & 1.02 & & & \\
\hline
\end{tabular}

Table 10 shows a significant difference according to the department $[\mathrm{t}(96)=3.42, \mathrm{p}<.05]$. Classroom teacher candidates' attitudes $(\mathrm{X}=2.37)$ are higher than social sciences teacher candidates $(\mathrm{X}=1.63)$

Table 10. "I will regularly use educational digital games throughout the school” item's t-test results

\begin{tabular}{ccccccc}
\multicolumn{8}{c}{ according to department } \\
\hline Department & $\mathrm{N}$ & $\bar{X}$ & $\mathrm{~S}$ & $\mathrm{sd}$ & $\mathrm{t}$ & $\mathrm{p}$ \\
\hline Social sciences & 56 & 1.63 & 1.19 & 96 & 3.42 & .00 \\
Classroom teaching & 44 & 2.37 & .84 & & & \\
\hline
\end{tabular}

Table 11 shows a significant difference according to the department $[\mathrm{t}(98)=2.02, \mathrm{p}<.05]$. Classroom teacher candidates' attitudes $(\bar{X}=2.86)$ are higher than social sciences teacher candidates $(\bar{X}=2.41)$.

Table 11. "Educational digital games provide opportunities for more efficient learning" item's t-test results

\begin{tabular}{ccccccc}
\multicolumn{7}{c}{ according to department } \\
\hline Department & $\mathrm{N}$ & $\bar{X}$ & $\mathrm{~S}$ & $\mathrm{sd}$ & $\mathrm{t}$ & $\mathrm{p}$ \\
\hline Social sciences & 56 & 2.41 & 1.17 & 98 & 2.04 & .04 \\
Classroom teaching & 44 & 2.86 & 1.00 & & & \\
\hline
\end{tabular}

The items "Educational digital games enrich our learning experience to a degree that requires extra effort" and "Playing digital educational games do not frighten me in any way" can be interpreted as male teacher candidates present a more positive opinion as they like more playing digital games and show more interest. Lowrie and Jorgensen reported in their study that [14] men play more games than women. In addition, the study conducted by Onay, Tüfekçi and Çağıltay in order to determine university students' playing habits and game preferences were found to be higher among male students. The studies also support this view [15].

Unal, Inan, Kaya, Firat, Güzelbaba and Bahadir declared in their research on teacher candidates that these have positive opinions about computer games. In the study, it is stated that teacher candidates mostly play computer games for entertainment/pleasure, let off steam, and appreciate leisure time, curiosity and motivation. It has been proposed that teacher candidates do not fully benefit from computer games although they have positive opinions about playing computer games for educational purposes [16]. Similarly, in the study conducted by Durdu, Hotomaroğlu and Çağıltay (the reason of university students' playing computer games was found to be to let off steam [17]. When the literature is examined, it is seen that teachers generally experience self-confidence problems in the process of integration of computer games into education, that they resist to new technologies, and that few of the teachers experience with games [18-20]. In this study too, it can be said that the reason of this concern in the teacher candidates is due to lack of knowledge about using digital games for educational purposes.

\section{CONCLUSION}

In this study, conducted on a total of 100 teacher candidates, 65 of whom were female and 35 were male, 56 were studying social sciences and 44 were in grade 4 of classroom teaching studies. On the basis of 
the items, it was determined that the one with the highest average among the 21 items is "I can learn a lot of information I have to know about a digital game by myself" while the item with the lowest average "I can hesitate to use an educational digital game with the concern that I might look stupid". These findings may be interpreted as the teacher candidates are concerned about their use although they believe that they will improve themselves in digital games. The average of the answers given by teacher candidates based on the scale show that they are uncertain. It can be said that teacher candidates should be informed about the use of educational digital games in their courses.

When the items "I'm afraid that I will have trouble playing around in the game when I'm given a chance to play a popular digital game", "I find it hard to learn if a subject is taught using a digital game", "I can hesitate to use an educational digital game with the concern that I might look stupid", "We can obtain many achievements we can get or reach using an educational digital game in other ways" are examined according to the department of study of teacher candidates, it can be observed that teacher candidates who study in classroom teaching department agree more with these articles. In this case, it can be said that teacher candidates studying in the social sciences department are more positive about using educational digital games than the teacher candidates studying in classroom teaching department, while the candidates studying in classroom teaching department are worried on this issue.

When the items "I will use educational digital games regularly throughout the school education", "Educational digital games provide opportunities for more efficient learning" are examined according to the department of study of teacher candidates, it was observed that teacher candidates studying classroom teaching agree more with these items. It can be said that the classroom teacher candidates who are more concerned about educational digital games than the teacher candidates studying social sciences are more willing and enthusiastic about using this method.

Since educational digital games will help to create an enriched and differentiated learning environment, teachers who will use these games will have a variety of tasks. Teachers should use these games correctly and effectively to achieve their goals. During the training of teacher candidates, necessary practices should be given about the use of educational technologies in learning environments. Seminars and on-the-job trainings on developing and changing technologies shall be given to the teachers in charge.

\section{REFERENCES}

[1] K. Çilenti., Eğitim Teknolojisi ve Öğretim. Kadığlu Matbaası: Ankara, 1979.

[2] B. Akkoyunlu., "Bilgisayar ve eğitimde kullanılması," Çağdaş Eğitimde Yeni Teknolojiler.Anadolu Üniversitesi Açık Ö̆gretim Fakültesi Yayınları, pp. 33-45, Eskişehir, 1998.

[3] E. Kamacı and E. Durukan.,"Araştırma Görevlilerinin Eğitimde Tablet Bilgisayar Kullanımına İlişkin Görüşleri Üzerine Nitel Bir Araştırma (Trabzon Örneği),"Uluslararası Türkçe Edebiyat Kültür Eğitim Dergisi, 2012.

[4] M. Prensky, "The motivation of gameplay: The real twenty-first century learning revolution,"On the Horizon, vol. 10(1), pp. 5-1, 2002.

[5] R. Garris, R. Ahlers \& J. E. Driskell., "Games, motivation, and learning: A research and practice model," Simulation and Gaming, vol. 33, pp. 441-467, 2002.

[6] V. Kukul, Eğitsel Dijital Oyunlar,” Mehmet Akif Ocak (Ed.), Oyunla ilgili tarihsel gelimler ve yaklaşımlar (s. 2031). Pegem Akademi, Ankara, 2013.

[7] M. B. Horzum.,"İlköğretim Öğrencilerinin Bilgisayar Oyunu Bağımlılı̆̆ı Düzeylerinin Çeşitli Değişkenlere Göre İncelenmesi," Eğitim ve Bilim, vol. 36(159), pp. 56-68, 2011.

[8] S. Çankaya and A. Karamete.,"Eğitsel Bilgisayar Oyunlarının Öğrencilerin Matematik Dersine ve Eğitsel Bilgisayar Oyunlarına Yönelik Tutumlarına Etkisi," Mersin Üniversitesi Eğitim Fakültesi Dergisi, vol. 4(2), pp. 115-127, 2008.

[9] B. Doğrusoy and Y. İnalı, "Çok Kullanıcılı Bilgisayar Oyunları ile Öğrenme, Simulations and Games in Education, "Eğitimde Simülasyon ve Oyunlar araştırma grubu," VII. Ulusal Fen bilimleri ve Matematik eğitimi kongresi, Ankara, Türkiye, 2006.

[10] M.Prensky, Digital game-based learnin. McGraw-Hill, New York, 2001.

[11] Ş. Büyüköztürk, Bilimsel Araştırma Yöntemleri. PegemA Akademi, Ankara, 2014.

[12] N.Karasar, Bilimsel Araştırma Yöntemi. Nobel Yayın Dağıtım, Ankara, 2005.

[13] O. Sarıgöz, Y. Bolat, \& S. Alkan., "Digital Educational Game Usage Scale: Adapting to Turkish, Validity and Reliability Study," World Journal of Education, vol. 8(5), 2018.

[14] T. Lowrie and R. Jorgensen.,"Gender Differences in Students' Mathematics Game Playing," Computers \& Education, vol. 57(4), pp. 2244-2248, 2011.

[15] P. Onay, A. Tüfekçi, \& K. Çağıltay.,"Türkiye'deki öğrencilerin bilgisayar oyunu oynama alışkanlıkları ve oyun tercihleri: ODTÜ ve gazi üniversitesi öğrencileri arası karşılaştırmalı bir çalışma," Bilişim Teknolojileri Işığında Eğitim Konferansı'nda sunulan bildiri, Ankara. 2005. 
[16] A. T. Ünal, F. İnan, M. T. Kaya, M. Fırat, Z. Güzelbaba, \& A. Bahadır, "Öğretmen adaylarının bilgisayar oyunu oynama alışkanlıkları, amaçları ve oyun tercihlerinin incelenmesi: Maltepe Üniversitesi örneği," AJIT-e: Online Academic Journal of Infornation Technology, vol. 4(12), DOI: 10.5824/1309-1581.2013.3.003.x,2013.

[17] P. O. Durdu, A. Hotomaroğlu, \& K. Çağıltay., "Türkiye'deki öğrencilerin bilgisayar oyunu oynama alışkanlıkları ve oyun tercihleri: Odtü ve gazi ünivesitesi öğrencileri arası bir karşılaştırma," Bilişsim Teknolojileri Işı̆̆ında Ĕgitim Konferansı'nda sunulan bildiri, Ankara, 2004.

[18] M. Demirbilek \& S. L. Tamer., "Math teachers' perspectives on using educational computer games in math education," Procedia Social ve Behavioral Sciences, vol. 9, pp. 709-716, 2010.

[19] A. Akıncı, M. Sırakaya, D. Yıldırım, \& H. Tüzün., "Eğitsel bilgisayar oyunlarının eğitim ortamlarına entegrasyonu,"4. Uluslararası Bilgisayar ve Öğretim Teknolojileri Sempozyumu Bildiriler Kitabl, pp. 108-112, Konya, Türkiye, 2010.

[20] J. Bourgonjon, F. D. Grove, C. D. Smet, J. V. Looy, R. Soetaert, \& M. Valcke., "Acceptance of game-based learning by secondary school teachers," Computers \& Education, vol. 67, pp. 21-35, 2013.

Int. J. Eval. \& Res. Educ. Vol. 8, No. 2, June 2019: 344 - 350 